\title{
Uma amizade impensável
}

\author{
José Arthur Gianotti \\ Universidade de São Paulo (USP)
}

Toda amizade tem sua zona de indefinição, em particular quando amigos discutem filosofia. Com Porchat, à exceção de quando o assunto era seu grande livro sobre Aristóteles, nunca me entendi. Já no Ginásio do Estado, como ele era tomista, eu me fazia de discípulo de Berkeley. No entanto, nossa grande diferença era como víamos e sentíamos a história. Aliás, até no modo de construir sua carreira, pois, aos passar de um domínio para outro - estudos clássicos, filosofia, lógica — sempre começava matriculando-se num curso de graduação. À exceção do ceticismo, quando mergulhou em Sexto Empírico fazendo dele a plataforma de onde saltava para outros autores.

Creio que sua posição tem algo a ver com sua indiferença ao marxismo, em particular ao sentido da história. Embora de esquerda, nunca deu atenção ao alerta de Sartre de que não era possível considerar os desafios políticos do momento sem levar em conta as provocações teóricas de Marx. Eu mesmo mergulhei nessa direção. Embora meu projeto de doutoramento fosse estudar a lógica de Husserl — que resultou numa crítica fenomenológica a Stuart Mill —, o contato com o grupo Socialisme et Barbarie, que conheci através de Claude Lefort, me obrigou a considerar a crise das revoluçôes socialistas. Se isso marcou a direção de meu trabalho, agora, no fim da vida, reconheço que terminei tendo uma leitura marxizante de Hegel, a despeito das advertências e do grande livro, La Patience du concept, de Gérard Lebrun.

Nada disso interessou a Porchat. Interpretou à la lettre as teses estruturalistas de Victor Goldschmidt, mas, se cada filosofia tem sua lógica, não é por isso que não compartilham temas comuns: o próprio Goldschmidt costumava fazer essas comparaçóes. Diante da diversidade dessas lógicas Porchat continua procurando pontos fundamentais que marcam sua história pessoal: "Continuo a ansiar pela Verdade, tenho a paixão da Humanidade, acredito firmemente na Realidade das coisas e nos eventos da experiência cotidiana e tenho uma consciência brutal da finitude de nossa razão" (Porchat, I993, p. 24). Mas "Verdade", "Humanidade", "Realidade", "Razão" não são conceitos cujos significados variam conforme se inserem nos sistemas filosóficos, sem que haja, nesse plano conceitual um único elo em comum, mas 
por semelhanças de família? Desconfio de que Porchat seja um pós-cético muito dogmático, assentado numa enorme erudição.

Esse meio ceticismo parcialmente racional já transparece em sua análise do ceticismo metodológico de Descartes. Se este suspende o juízo sobre todas as opiniôes que outrora recebera como verdadeiras, essa suspensão da verdade não nega a unicidade de cada ideia mental, de cada representação, valendo para qualquer discurso, seja o de Platão, seja o de São Tomaz. Ora, como Porchat analisa a hipótese do Deus enganador? Vejamos: "suporei, portanto, que há, não um Deus verdadeiro, [...] mas um certo gênio mau [...] que empregou toda sua indústria em enganar-me" (Descartes, I983 [I64I], p. XX). Ao contrário de Sexto Empírico, Descartes não aplica a epokhê universalmente, preservando a existência da alma. A dúvida é então radical só pela metade: "Somente em aparência, portanto, Descartes exacerbou a dívida cética até seu extremo limite" (Porchat, 1993, p. I6I). Diria eu, noutros termos, a dúvida radical diz respeito ao representado das representaçôes, pois só assim mantém intacta a alma como tal. Mas entre essas representaçóes reconhece-se a existência do representar de um Deus que, depois da evidência da existência do cogito, reata a verdade da representação com seu representado.

Esse não é o caminho do próprio Porchat? O ceticismo filosófico termina sendo apenas metodológico, quando, agarrado ao mundo, afirma "acredito firmemente na realidade das coisas e nos eventos da experiência cotidiana e tenho uma consciência brutal da finitude de nossa razão" como vimos acima. Daí sua ruptura com a filosofia: "Proponho uma ruptura com a filosofia bem mais radical do que a do ceticismo. Um mergulho profundo, definitivo e de alma inteira na vida cotidiana dos homens. Náo me limito a suspender meus juízos, mas em face dos jogos filosóficos ouso dizer: 'Não jogo mais'. Regresso à humanidade comum e assumo integralmente a sua não filosofia” (Ibid., p. 50). Esse não-jogo, porém, não é outro jogo? Por que Porchat não deixa de falar de filosofia, mas continua insistindo na diferença radical entre a filosofia e sua história?

O que, porém, esse não-filósofo entende por "jogos filosóficos"? Em primeiro lugar: "Duas filosofias em contato são sempre dois mundos que se enfrentam, visceralmente incompatíveis e ordenados sempre à negação do outro" (Ibid., p. I7). Ora, para Porchat esse enfrentamento se faz unicamente entre argumentos e contraargumentos, que para ele é o único ponto de vista racional. Esse confronto de juízos faz da epokhê unicamente uma suspensão de juízos apofânticos. E assim Porchat expulsa da filosofia toda fenomenologia que sempre é meramente descritiva, nem sempre dependendo desse tipo de proposição. Hegel é o primeiro a ser excluído do mundo filosófico, pois a contradiçáo é caminho pelo qual o Espírito se apresenta. Husserl também há de seguir pelo mesmo caminho, mesmo nos seus escritos finais 
quando estuda o entrelaçamento do juízo com a experiência. Heidegger, embora ele o cita a respeito de sua concepçáo de filosofia, seria o espantalho que transfere o juízo para a esfera da prônesis, pois o entender é uma possibilidade do ser-aí [Dasein] um ente que cuida, trata de seu ser.

Uma última palavra sobre esse mergulho de Porchat no mundo cotidiano. Mundo deixa de ser um conceito, mas a base da existência porchatiana. Suas várias significaçóes, quer do ponto de vista da filosofia, quer da linguagem cotidiana, fundem-se numa aceitação radical da vida comum. Mas não deveria então cuidar mais da política, das contradiçóes injustas que racham esse mundo?

\section{Bibliografia}

Descartes, R. (1983 [164I]). Meditaçôes. Col. "Os Pensadores”. São Paulo: Ed. Abril. Porchat Pereira, O. (1993). Vida comum e ceticismo. São Paulo: Brasiliense. 